čitatelovi existenciálnu komunikáciu ako neodmyslitelnú zložku vzájomných vzt’ahov medzi ludmi, v ktorej ,... by sme mali hladat' zmysel dejín, nie vo vojnových konfliktoch, bratovražedných bojoch, krvavých udalostiach, ktoré síce aktívne vstupujú do ludskej každodennosti, nedávajú však konečný zmysel ludským projektom"3. Monografia v mnohých ohladoch inšpiruje a dodáva impulz pre dalšie bádanie v oblasti prienikov umeleckej literatúry a vedy, čím vo výsledku prispieva k rozširovaniu povedomia o kultúrno-civilizačných súvislostiach.

Igor Cintula

\title{
Literatúra:
}

HAJKO, D.: Literatúra ako existenciálna komunikácia. Bratislava: VSSS, 2019, $167 \mathrm{~s}$. ISBN 978-80-8202-103-8.

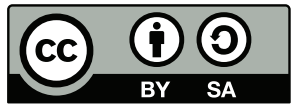

This work can be used in accordance with the Creative Commons BY-SA 4.0 International license terms and conditions (<https://creativecommons.org/licenses/by-sa/4.0/legalcode>). This does not apply to works or elements (such as images or photographs) that are used in the work under a contractual license or exception or limitation to relevant rights.

\section{Осмысление категории времени в книге «Czas w kulturze rosyjskiej. Время в русской культуре»}

DUDEK, A. (red.): Czas w kulturze rosyjskiej. Время в русской культуре. Kraków: Wydawnictwo Księgarnia Akademicka, 2019. Seria Antropologia Kultury Rosyjskiej. ISBN 978-83-8138-138-3.

Книга «Время в русской культуре» (польск. «Czas w kulturze rosyjskiej») (2019) под редацией Andreja Dudka является сборником статей исследователей, представляющих университеты и исследовательские центры семи стран (Польши, России, Чехии, Литвы, Франции, Казахстана, Украины), и посвящена вопросу представления о сущности времени, сохранившегося в сознании русских людей и отраженного в русской литературе, языке, изобразительном искусстве, кино, политике, истории, философии и культуре. 
Книга состоит из шести глав.

В первой главе «Время в языке. Язык во времени» категория времени рассматривается как компонент, отраженный в русском языке. Так, Ewa Komorowska, анализируя толковые и фразеологические словари русского языка, отмечает активное использование слова «время» в русских фразеологизмах, а также представляет их классификацию в соответствие с характеристиками данной категории. Алла Лихачева рассматривает время как фактор, влияющий на современный российский городской дизайн, а именно на названия городских объектов. Автор статьи показывает поворот к традиционному в городской номинации, напр., к советскому и перестроечному периоду, и объясняет это тем, что культура является источником воспоминаний и образов и формирует коллективную идентичность.

Глава «Сакральные и мифологические ритмы времени» открывается статьей Елены Левкиевской, которая, используя записи Полесской этнолингвистической экспедиции и фольклорные публикации, рассматривает принципы конструирования миффологического времени и делает вывод о том, что в русской картине мира существует несколько его моделей (циклическое, календарное время и др.) Hanna Kowalska-Stus пишет о эсхатологическом пространственном восприятии истории в русской культуре, отмечая большое влияние на нее византийской культуры и христианства. Кроме того, данная глава содержит статьи об историческом и сакральном времени в современном российском кинематографе (фильмах А. Тарковского, А. Звягинцева, А. Сокурова, А. Балабанова); о житие Кирилла Белоозерского, в котором Jósef Kuffel выделяет пять временных аспектов; о деятельности международной общественной организации «Радастея» и отмеченной ею важности ритма и времени в жизни человека; об особом виде сакрального времени - поста в жизни и творчестве Андрея Муравьева.

Глава «Осмысление времени в русской богословской и философской мысли» включает в себя статьи, посвященные рассмотрению энантиодромии как обобщенной формы времени в русской культуре Серебряного века (в том числе, в трудах Вяч. Иванова), а также проблеме времени в работах некоторых философов: А.Шмемана, определяющего проявление человеческого в той мере, в какой устанавливается связь с чем-то вневременным; П. А. Флоренского, рассматривающего антиномию «миг-вечность» в связи с другой - «феномен-ноумен»; А. Ф. Лосева, воспринимающего случайные эпизоды человеческой жизни как вечное, вселенское мгновение, временное целое; Н. А. Бердяева, сопоставляющего временное и вечное; Ф. Степуна, определяющего маскарад как проявление трансцендентальности, желания обрести вечность в хороводе масок, смене ролей; Д. Чижевского, посвятившего свои работы вопросам 
интерпретации реального, мистического, исторического, экзистенциального, психологического времени в художественных произведениях.

В главе «Культурологическое и историческое осмысление времени» Ириной Колесник проведен анализ категории времени в культуре, выделены этапы его социализации, начиная от появления древнего человека и заканчивая современным глобализующимся миром, определена рецепция времени в культурной традиции Восточной и Западной Европы. Автор приходит к выводу, что в культурах различных народов на разных исторических этапах возникает неодинаковое его восприятие. Ирина Едошина, автор статьи «Эпоха fin de siècle: культурфилософские очертания», рассматривает эпоху Серебряного века и отмечает, что эпоха fin de siècle завершила классический период в истории развития художественной культуры и явилась основой для появления модернизма. Последняя статья данной главы написана Александром Турыгиным, который описывает в ней теорию «переломного времени» Р. Козеллека. Автор статьи отмечает, что данное понятие предполагает некий исторический период, когда происходило формирование того или иного понятия, и что Р. Коззелек видит в анализе языка исторического источника способ интерпретации истории.

«Время как аспект общественной жизни» - пятая глава данной книги, в которой время рассматривается как фактор, оказывающий влияние на жизнь русского человека. Авторы некоторых статей, входящих в данный раздел, показывают, как конкретные исторические события и эпохи воздействовали на русское общество. Так, Ирина Синова пишет, что Революция 1917 года повлияла на политико-воспитательную, культурно-массовую работу людей, а также вызвала у них слепую веру в будущее. Алла Сальникова отмечает, что советская эпоха воспринималась людьми как рубеж, начало другой жизни, что отражено в исследуемых ею детских автобиографических нарративах первых лет советской власти. Anna Kadykało показывает в своей статье эволюцию восприятия советско-афоганской войны в общественном сознании россиян: от забвения до приобретения ею прочного места в памяти людей. Кроме того, в данной главе представлены статьи, посвященные отражению в национальной татарской литературе реалий нового советского периода, трансформации понятий «раньше» и «теперь» в памяти русского народа, ощущению времени в передовой российской педагогике XX века и др.

Глава «Временные аспекты литературной картины мира» содержит статьи, посвященные роли времени в русской литературе XIX-XXI веков. Василий Щукин рассматривает художественные модели исследуемой категории в русской литературе XIX века: мифическое, циклическое, метаисторическое, макрокалендарное, биографическое, репортерское время и вечность. О русском 
травелоге XIX века пишет Михаил Строганов, показывая своим исследованием то, что человек с помощью времени пытается одолеть пространство. Константин Баршт анализирует произведения Ф.М. Достоевского и делает вывод, что персонажи писателя существуют и в трехмерном мире, и одновременно в вечности и беспредельной Вселенной, наделенной смыслом. Светлана Титаренко рассматривает вечное возвращение Ницше как форму выражения философского сомнения в поэзии серебряного века. Йозеф Догнал определяет роль времени в повести А. М. Ремизова «Часы», в которой показано столкновение смертного человека с линеарным временем и обретение им победы над ним. Andrej Dudek выделяет временные аспекты картины мира в творчестве Д. Мережковского: опозиции времени и вечности, вечности и мгновения, категорию «духа времени» и др. Несколько статей последней главы посвящены категории времени в современной литературе. Так, Кристина Воронцова рассматривает время как постмодернистсткую игру, Martyna Kowalska пишет, что современная российская драматургия показывает хаос современности и подчеркивает необходимость в осознании прошлого. Также данная глава включает в себя статьи, посвященные исследованию временного аспекта в творчестве М. Шишкина, А. П. Чехова, А. Блока, А. Солженицына, М. Горького и других писателей.

Анализ явлений русской культуры, философии и исторических и политических реалий авторами данного сборника представляет разносторонний подход к категории времени. Статьи, составляющие сборник, написаны на польском и русском языках, каждая из них открывается аннотацией и ключевыми словами на английском языке.

Но несмотря на все достоинства данного издания и его большой объем (626 стр.), хотелось бы видеть в нем больше статьей, посвященных отражению времени в русском языке, а также культурологическому и историческому осмыслению данной категории.

Книга может быть полезна для научных работников, преподавателей, аспирантов, студентов искусствоведческих, исторических, философских, культурологических факультетов высших учебных заведений, а также для всех интересующихся русской культурой.

Юлия Алексеевна Дмитриева 


\section{Литература:}

DUDEK, A. (red.): Czas w kulturze rosyjskiej. Vremja v russkoj kul'ture. Kraków: Wydawnictwo Księgarnia Akademicka, 2019. Seria Antropologia Kultury Rosyjskiej. ISBN 978-83-8138-138-3.

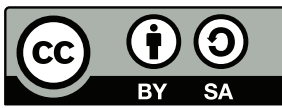

This work can be used in accordance with the Creative Commons BY-SA 4.0 International license terms and conditions (<https://creativecommons.org/licenses/by-sa/4.0/legalcode>). This does not apply to works or elements (such as images or photographs) that are used in the work under a contractual license or exception or limitation to relevant rights.

https://doi.org/10.5817/0S2021-3-12

\section{Eurasijci, Eurasie a eurasijská studia v kontextu ruského světa}

FRIESS, N., KAMINSKIJ, K. (eds): Resignification of borders: Eurasianism and the Russian world. Berlin: Frank \& Timme, Verlag für wissenchaftliche Literatur, 2019. Ost-West-Express, Band 37. ISBN 978-3-7329-0570-6.

„Suddenly, ,Eurasia“ is everywhere“ - tímto postřehem ze studie Stephena Kotkina začíná úvodní článek nové kolektivní monografie věnované problematice eurasijství a koncepci tzv. Ruského světa. Publikace byla sestavená pod editorským dohledem Niny Friess a Konstantina Kaminského, kteří v současnosti působí na Humboldtově univerzitě v Berlíně (Katedra slovanských studii) a přináší řadu tematicky široce uchopených studií, soustředěných na reflexi eurasijských koncepcí zejména v geopolitickém a kulturním areálu Ruska a Střední Asie.

Úvodní editorský článek si klade za cíl nejen stručné představení jednotlivých textů, ale poskytuje i zásadní a metodologicky zajímavě uchopený pohled na eurasijské koncepce a jejích vztah k problematice Ruského světa. Kromě nutného představení eurasijství jako ideologického hnutí, jež vzniklo v prostředí meziválečné ruské emigrace se Friess a Kaminskij soustředili zejména na to, jakým způsobem se v současnosti s tímto termínem operuje v kontextu širšího akademického diskursu. Právě v tomto ohledu je zde citován výše uvedený postřeh Stephena Kotkina, jež v první dekádě 21. století poukázal na výraznou rozpínavost eurasijství nikoliv jako specifické ideologie, ale jako pojmu, jež se zejména v západním akademickém prostředí postupně stal synonymem pro označování post-sovětského geopolitického a kulturního prostoru. 